\title{
O administrador e as máquinas
}

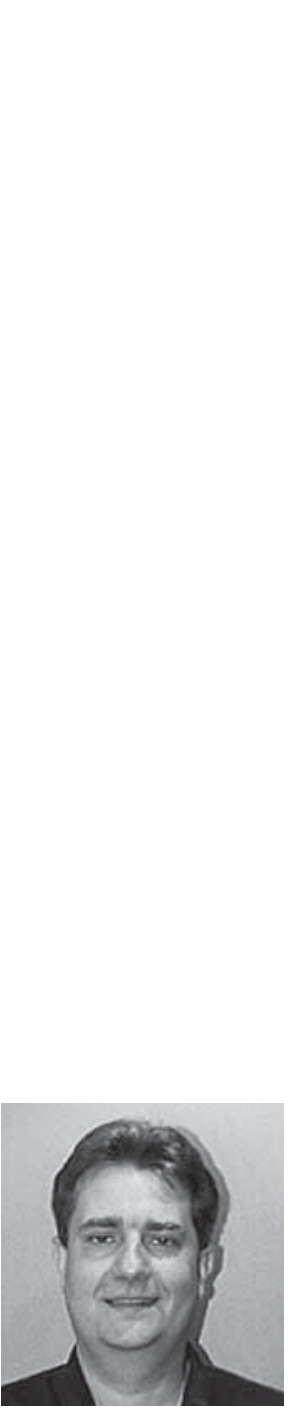

Antonio Gelis Filho

FGVEAESP

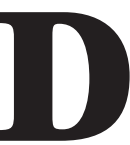

urante boa parte da história, o ser humano preocupou-se em ser diferente dos animais; para tanto, esperava-se que fôssemos capazes de agir com a razão, controlando nossos instintos e emoções inadequadas.

É um interessante sinal dos tempos que nossa preocupação atualmente seja nos diferenciarmos das máquinas. Não queremos "trabaIhar como máquinas", "agir como máquinas", "viver como uma máquina". Espremidos entre a sombra dos animais e a das máquinas que não devemos ser, tentamos agir como administradores eficazes mas também humanos, racionais mas também sensíveis, intuitivos mas também lógicos. Super-homens e supermulheres, na mente e no coração.

Essa pressão por uma perfeição inumana talvez seja um dos fatores responsáveis pelos sintomas de desajuste organizacional que tanto preocupam os gestores de hoje, tais como burnout, falta de criatividade e inovação, ausência de comprometimento e de ética.

É preciso notar quena raiz dessa pressão toda existe uma falsa premissa: a de que as máquinas, sejam computadores ou prensas, podem substituir o ser humano. É verdade que determinadas ocupações são mais bem realizadas por máquinas; entretanto, é verdade também que o responsável último por essa máquina é um ser humano, que a projetou, construiu ou programou.
Uma das conseqüências dessa falsa premissa é a comparação, consciente ou não, do desempenho dos seres humanos com o desempenho das máquinas.

Qualquer busca de uma "eficiência mecânica" da parte de um gestor em relação a seus colaboradores estará fadada ao fracasso. Não apenas pela incapacidade do ser humano de agir repetitivamente com a mesma previsibilidade, eficiência e eficácia que as máquinas, mas também pela incapacidade do ser humano em deixar de criar, de intuir, de sentir, de improvisar e de inovar.

Em uma economia que se pretende "do conhecimento e da inovação", como tantos pretendem que seja a economia dos nossos tempos, a existência de máquinas capazes de um desempenho tão útil quanto é o dos computadores não deve nos levar a tomá-las como "metro" contra o qual se medirá o desempenho dos seres humanos.

Se queremos inovação e criatividade, não devemos confundir criador e criatura. Em sua origem, no grego antigo, a palavra "máquina" estava relacionada à idéia de "meio", utilizado para potencializar a ação humana e não para substituí-la.

Entre os animais e as máquinas há muito espaço para o ser humano agir como tal, em toda a sua imprevisibilidade tão cheia de maravilhosas possibilidades. 